\title{
On the reaction between oxazole and benzyne
}

\author{
Sonsoles Pérez, Enrique Guitián, ${ }^{*}$ and Luis Castedo \\ Departamento de Química Orgánica y Unidad Asociada al CSIC, \\ Universidad de Santiago, 15706 Santiago de Compostela. SPAIN \\ (received 24 Mar 00; accepted 21 Sep 00; published on the web 29 Sep 00)
}

\begin{abstract}
Oxazole reacts with benzyne generated from benzenediazonium 2-carboxylate to afford the polycyclic compound 4. This compound is a close analog of the neuroprotective and anticonvulsive agent MK-801.
\end{abstract}

Keywords: Oxazole, benzyne, benzenediazonium carboxylate.

\section{Introduction}

In the course of a project aimed at the synthesis of compounds of pharmacological interest with an isoquinoline nucleus we focused our attention on the reactivity of oxazoles with benzyne. Initial analysis suggested that isoquinoline derivatives might be obtained by a Diels-Alder reaction between both reagents. However, a literature survey showed a more complex situation. When benzyne was generated by decomposition of benzenediazonium 2-carboxylate at $100{ }^{\circ} \mathrm{C}$ in the presence of oxazoles 1 , anthracene oxides 3 were obtained. ${ }^{1}$ These compounds were formed by a retro-Diels-Alder reaction of the initial cycloadducts 2 to lose a nitrile $\left(\mathrm{R}_{2} \mathrm{CN}\right)$ followed by addition of a second benzyne to the intermediate isobenzofuran, to form the 2:1 adducts. When benzyne was generated at lower temperature by the oxidation of aminobenzotriazole in the presence of 4-phenyloxazole (1) the retro-Diels-Alder reaction did not occur and the initial cycloadduct 2 was isolated in good yield. ${ }^{2}$

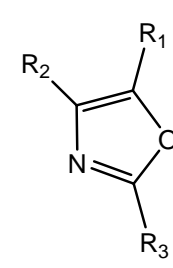

1

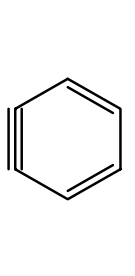

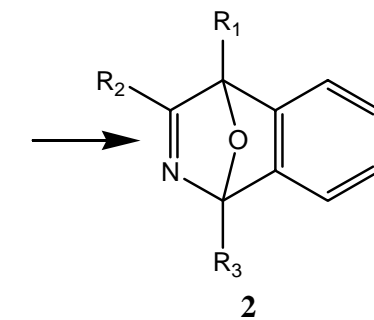

2<smiles>[R3]C12OC([R3])(c3ccccc31)c1ccccc12</smiles>

3

\section{Scheme 1}


With these antecedents we decided to study the reaction between oxazole itself and benzyne generated by decomposition of benzenediazonium 2-carboxylate at temperatures lower than $100^{\circ} \mathrm{C}$. When a suspension of benzenediazonium 2-carboxylate (5 equiv.) in 1,2dimethoxyethane was added to a refluxing solution (approx. $80^{\circ} \mathrm{C}$ ) of oxazole (1 equiv.) in the same solvent neither isoquinoline oxide nor anthracene oxide were isolated. Instead we obtained a $25 \%$ yield of a product to which we assigned the structure 4 based on the spectroscopic evidence. We propose the mechanism as shown in Scheme 2 for the formation of 4.

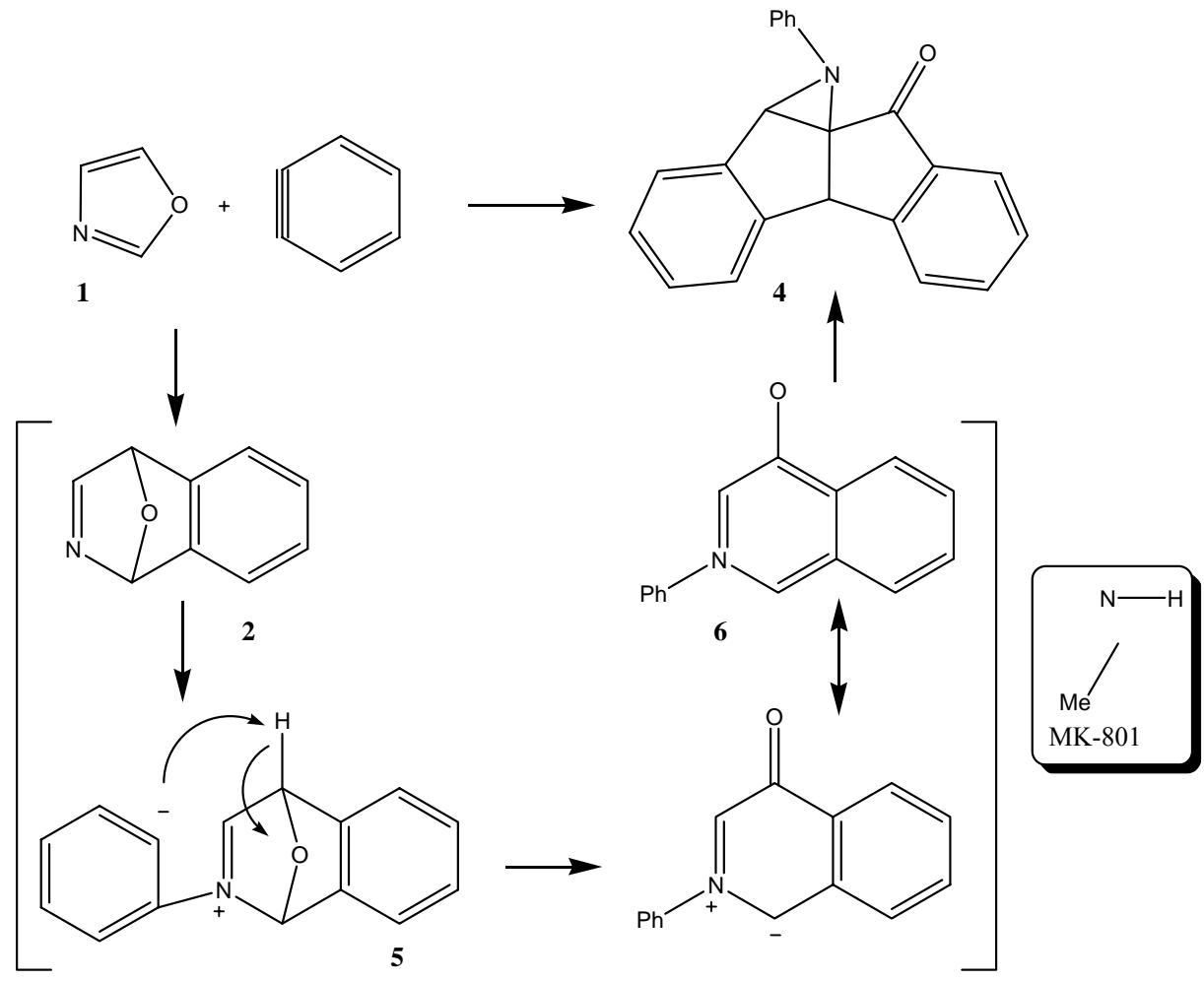

\section{Scheme 2}

The initial adduct 2 reacts with benzyne to form the zwitterion 5, which by a proton abstraction and oxide opening affords the 1,3-dipole 6. This reacts with benzyne in a 1,3 dipolar cycloaddition pathway to form the final product 4 .

At this point we realized that Katritzky and coworkers had previously studied the reaction between 6 and benzyne. ${ }^{3}$ Comparison of the spectroscopic data ${ }^{3}$ indicates that the compound 4 is identical to the one reported by Katritzky's group. ${ }^{3}$ This fact confirms the structure of our product and supports the mechanism proposed for its formation.

In summary, this reaction constitutes a one-pot synthesis of a close analog of the compound MK$801,{ }^{4,5}$ a potent anticonvulsive and neuroprotective agent, ${ }^{6}$ which is a selective ligand for cyclidine brain receptors and inhibits opioid tolerance and dependence. ${ }^{7,8}$ Further work is in progress to investigate the scope of this reaction. 


\section{Experimental Section}

Excess isoamyl nitrite $(1.67 \mathrm{~g}, 14.5 \mathrm{mmol})$ was added over 1-2 $\mathrm{min}$ to an ice-cooled stirred solution of anthranillic acid $(1.00 \mathrm{~g}, 7.25 \mathrm{mmol})$ in dry DME $(10 \mathrm{~mL})$ containing a catalytic amount of trichloroacetic acid. The ice-bath was removed after $15 \mathrm{~min}$, and the mixture turned brown-red as it reached room temperature. This mixture was stirred for $30 \mathrm{~min}$. After dilution with DME the supernatant layer was discarded (aspiration through teflon tubing into a plastic syringe is recommended). Caution: when dry, benzenediazonium-2-carboxylate detonates violently on being scraped or heated. The remaining material was washed several times with DME until neutral. The resulting brownish precipitate was suspended in solvent and with the aid of a plastic syringe with teflon tubing (never with a metal needle!) was added slowly to a solution of oxazole $(100 \mathrm{mg}, 1.45 \mathrm{mmol})$ in dioxane $(10 \mathrm{~mL})$ at $60^{\circ} \mathrm{C}$. The reaction was monitored by tlc until the starting material disappeared. The solvent was then removed "in vacuo" and the residue chromatographed on silicagel plates (typically with dichloromethane as eluent), to afford a $25 \%$ yield of compound 4 ; mp 196-198 $\mathrm{C}(\mathrm{EtOH})$.

\begin{tabular}{ll}
\hline${ }^{1} \mathrm{H} \mathrm{NMR}\left(\mathrm{CDCl}_{3}\right), \delta$ & $7.60(\mathrm{~d}, J=7.6 \mathrm{~Hz}, 1 \mathrm{H}, \mathrm{ArH}), 7.59-7.55(\mathrm{~m}, 1 \mathrm{H}, \mathrm{ArH}), 7.44-7.34(\mathrm{~m}, 3 \mathrm{H}$, \\
& $\mathrm{ArH}), 7.26-7.15(\mathrm{~m}, 5 \mathrm{H}, \mathrm{ArH}), 6.88(\mathrm{~d}, J=7.8 \mathrm{~Hz}, 2 \mathrm{H}, \mathrm{ArH}), 6.78(\mathrm{t}, J=$ \\
& $7.3 \mathrm{~Hz}, \mathrm{ArH}), 5.89(\mathrm{~s}, 1 \mathrm{H}, \mathrm{CH}), 5.49(\mathrm{~s}, 1 \mathrm{H}, \mathrm{CH}) \mathrm{ppm}$ \\
${ }^{13} \mathrm{C} \mathrm{NMR}\left(\mathrm{CDCl}_{3}\right), \delta$ & $192.5,146.9,146.0,143.7,137.4,133.9,129.5,128.3,128.1-127.5$, \\
& $124.5,124.3,121.7,119.9,116.1,72.3,65.9 \mathrm{ppm}$. \\
\hline $\mathrm{IR}(\mathrm{film}) \operatorname{vmax}$ & $1690(\mathrm{CO}) \mathrm{cm}^{-1}$. \\
\hline $\mathrm{MS} \mathrm{m} / \mathrm{z}(\%):$ & $297\left(\mathrm{M}^{+}, 40\right), 268(100)$. \\
\hline
\end{tabular}

\section{Acknowledgements}

To the DGICYT for financial support (Project Number PB93-0533) and the Xunta de Galicia for the research grant awarded to S.P.

\section{References}

1. Reddy, G. S.; Bhatt, M. V. Tetrahedron Lett. 1980, 21, 3627.

2. Withney, S. E.; Rickborn, B. J. Org. Chem. 1988, 53, 5595. 
3. Dennis, N.; Katritzky, A. R.; Parson, S. K. J.C.S. Perkin I 1976, 2285.

4. Clinesschmidt, B.V.; Martin, G.E.; Bunting, P.R. Drug Dev. Res. 1982, 2, 123.

5. For a related work see: Constable, K. P.; Blough, B. E.; Carroll, F. I. J. Chem. Soc. Chem. Commun. 1996, 717.

6. Loo, P. A.; Braunwalder, A. F.; Williams, M.; Sills, M. A. Eur. J. Pharmacol. 1987, 135, 261. McDonald, J. W.; Silverstein, F. S.; Johnson, M. Eur. J. Pharmacol. 1987, 140, 359.

7. Thompson, W. J.; Anderson, P. S.; Britcher, S. F.; Lyle, T. A.; Thies, J. E.; Magill, C. A.; Varga, S. L.; Schwering, J. E.; Lyle, P. A.; Christy, M. E.; Evans, B. E.; Colton, C. D.; Holloway, M.K.; Springer, J. P.; Hirshfield, J. M.; Ball, R. G.; Amato, J. S.; Larsen, R. D.; Wong, E. H. F.; Kemp, J. A.; Tricklebank, M. D.; Singh, L.; Oles, R.; Priestly, T.; Marshall, G. R.; Knight, A. R.; Middlemiss, D. N.; Woodruff, G. N.; Iversen, L. L. J. Med. Chem. 1990, 33, 789.

8. Trujillo, K. A.; Akil, H. Drug and Alcohol Dependence 1995, 38, 139. 